ORIENTAL JOURNAL OF CHEMISTRY

An International Open Free Access, Peer Reviewed Research Journal

www.orientjchem.org
ISSN: 0970-020 X

CODEN: OJCHEG

2014, Vol. 30, No. (2):

Pg. 849-851

\title{
One-Pot Synthesis of 1,8-Dioxo-octahydroxanthene Derivatives Using $\mathrm{Zn}\left(\mathrm{NO}_{3}\right)_{2}$ under Solvent-free Conditions
}

\author{
SEYED AMIR HASAN VAHABI , FARHAD HATAMJAFARI and KHALIL POURSHAMSIAN*
}

\author{
Department of Chemistry, Faculty of Science, \\ Islamic Azad University-Tonekabon Branch, Tonekabon, Iran. \\ *Corresponding author E-mail: kshams48@gmail.com \\ http://dx.doi.org/10.13005/ojc/300262
}

(Received: March 05, 2014; Accepted: March 15, 2014)

\begin{abstract}
$\mathrm{Zn}\left(\mathrm{NO}_{3}\right)_{2}$ as an efficient catalyst have been used for the one-pot synthesis of 1,8-Dioxooctahydroxanthene Derivatives via multi-component reactions between dimedone and various aromatic aldehydes under solvent-free conditions. The presented method is available, environmentally friendly, cheap and highly effective to give the products in good to excellent yields.
\end{abstract}

Key words: Xanthenes, Solvent-free, Multicomponent reactions, $\mathrm{Zn}\left(\mathrm{NO}_{3}\right)_{2}$.

\section{INTRODUCTION}

Multicomponent reactions (MCRs) refers to a reaction in which two or more ingredients are combined within a single process and the products they create, which is part of all the components are present ${ }^{1-3}$. Since the multi-component reactions for the synthesis of organic compounds and these compounds can be used as a drug and precursor multicomponent reactions, so to investigate them out is important ${ }^{4}$.

In our ongoing research prompted by our interest in multiple component reactions and as part of programs in the area of heterocyclic compounds containing oxygen, and due to the resultant pharmacological interest in compounds which belong to the xanthene Derivatives, although this reaction done $^{5}$.
Xanthene derivatives are one of the important classes of organic compounds which are biologically important drug intermediates in the field of medicinal chemistry for their biologically active properties, such as antimalarial, antibacterial, antiinflammatory, and antiviral properties and have been used as dyes, fluorescent material and in laser technologies ${ }^{6-9}$. Recently, several improved methodologies have been developed that use triethylbenzyl ammonium chloride ${ }^{10}, p$-dodecyl benzenesulfonic acid ${ }^{11}$, phosphomolybdic acid supported on silica gel ${ }^{12}$, sulfonic acid on silica gel $^{13}, \mathrm{HClO}_{4}-\mathrm{SiO}_{2}{ }^{14}$ and $\mathrm{ZnO}{ }^{15}$ among others. Previously, we have synthesized a number of heterocyclic compounds ${ }^{16-26}$.

In this study, we have used of $\mathrm{Zn}\left(\mathrm{NO}_{3}\right)_{2}$ as a catalysts to develop a new and easy methodology for the synthesis of xanthene derivatives. The 
experiments were started with the study of one pot reaction, a short time with high yields, easy separation of product, and a 3-component method, mild and efficient method for the preparation of the xanthenes by using $\mathrm{Zn}\left(\mathrm{NO}_{3}\right)_{2}$ as a catalyst (Scheme1).<smiles>[R]c1ccc(C=O)cc1</smiles><smiles>[R]c1ccc(C2C3=C(CC(C)(C)CC3=O)OC3=C2C(=O)CC(C)(C)C3)cc1</smiles>

\section{Scheme 1:}

\section{EXPERIMENTAL}

All chemicals were obtained from Merck or Fluka without further purification. Silica gel SILG/UV 254 plates were used for TLC. IR spectra were measured on a Shimadzu IR-470 Spectrophotometer. ${ }^{1} \mathrm{H}$ NMR spectra were determined on Bruker 400 DRX AVANCE instrument at $400 \mathrm{MHz}$, respectively.

\section{General procedure for preparation of A1}

A mixture of aldehyde (1 mmol), dimedone (2 mmol), and $\mathrm{Zn}\left(\mathrm{NO}_{3}\right)_{2}(6 \mathrm{~mol} \%)$ as a catalyst was stirred at $110^{\circ} \mathrm{C}$ for $10 \mathrm{~min}$. The progress of reaction was monitored by TLC. After finishing, recrystallized from ethanol $95 \%$ to give pure products (A1)

\section{Spectral data}

3,4,6,7-tetrahydro-3,3,6,6-tetramethyl-9-(3nitrophenyl)-2H-xanthene-1,8(5H,9H)-dione (A1) White crystals, Yield: (90\%), mp $171-174^{\circ} \mathrm{C}$. IR ( $v_{\max }$ ' $\mathrm{cm}^{-1}$ ) (KBr): 3074 (arom. CH Str.); 2990 (aliph. CH Str.); 1660 (C=O Str.); 1622 (C=C Str.); 1500, 1360
(NO2,Str). ${ }^{1} \mathrm{H}$ NMR (400.22 $\left.\mathrm{MHz} \mathrm{CDCl}_{3}\right): \delta=1.00(6 \mathrm{H}$, $\left.\mathrm{s}, 2 \mathrm{CH}_{3}\right) ; 1.12\left(6 \mathrm{H}, \mathrm{s}, 2 \mathrm{CH}_{3}\right) ; 2.19(4 \mathrm{H}, \mathrm{ABq}$, $\left.{ }^{3} \mathrm{~J}=16.4 \mathrm{~Hz}, 2 \mathrm{CH}_{2}\right) ; 2.52\left(4 \mathrm{H}, \mathrm{s}, 2 \mathrm{CH}_{2}\right) ; 4.84(\mathrm{H}, \mathrm{s}$, $\mathrm{CH}) ; 7.28$ 8.04- $(4 \mathrm{H}, \mathrm{m}, \mathrm{CH})$.

\section{RESULTS AND DISCUSSION}

We have been able to introduce an efficient and environmentally friendly for the synthesis of xanthene derivatives via condensation of dimedone with various aromatic aldehydes and ammonium acetate. Therefore, reported $\mathrm{Zn}\left(\mathrm{NO}_{3}\right)_{2}$ as catalyst which could provide an efficient, cheap, easy separation, high yield and simple route under solvent-free condition for the synthesis of 1,8-Dioxooctahydroxanthenes.

\section{ACKNOWLEDGEMENTS}

We gratefully acknowledge the financial support from the Research Council of Tonekabon Branch Islamic Azad University.

\section{REFERENCES}

1. Domling A., Chem. Rev., 2006.,106: 17

2. Khan A. J and Basheer M., Orient. J.Chem., 2011.,27(4): 1759-1762

3. Setamdideh D., Karimi Z and Rahimi F., Orient. J.Chem., 2011. 27(4): 1621-1634

4. Kalinski C., Lemoine H., Schmidt J., Burdack C., Kolb J., Umkehrer M. and Ross G., Syn. lett., 2008. 24: 4007

5. Peet N. P., Huber, E.W. and Huffman, J. C., J.
Heterocycl. Chem. 1995.,, 32: 33

6. Schumacher K., Ravikovitch P.I., Du Chesne A., Neimark A. and Unger K. K., Langmuir2000. 16: 4648

7. Chibale K., Visser M., Schalkwyk D. V., Smith P. J., Saravanamuthu A. and Fairlamb A. H., Tetrahedron 2003,59(13): 2289

8. Hideo T., Jpn. Tokkyo Koho JP 56005480., Chem. Abst. 1981., 95: 80922b 
9. Poupelin J. P., Saint-Rut G., Fussard-Blanpin O., Narcisse G., Uchida-Ernouf G. and Lakroix R., Eur. J. Med. Chem., 1978., 13: 67

10. Wang X. S., Shi D. Q., LiY. L., Chen H., Wei X. Y. and Zong Z. M., Synth Commun., 2005. 35, 97

11. Jin T. S., Zhang J. S., Xiao J. C., Wang A. Q. and Li T. S., Synlett., 2004 . 866

12. Srihari P., Mandal S. S., Reddy J. S. S., Srinivasa Rao R. and Yadav J. S., Chin Chem Lett., 2008,19, 771.

13. Mahdavi G. H., Bigdeli M. A. and Saeidi Hayeniaz Y., Chin Chem Lett., 2009.20, 539

14. Kantevari S., Bantu R. and Nagarapu L., J Mol Catal A: Chem., 2007.,269, 53

15. Maghsoodlou M. T., Habibi-Khorassani S. M., Shahkarami Z., Maleki N. and Rostamizadeh M., Chin Chem Lett 2010., 21, 686.

16. Azizian J., Hatamjafari F., Karimi A. R. and Shaabanzadeh M., Synthesis. 2006.5: 765
17. Azizian J., Shaabanzadeh M., Hatamjafari F. and Mohammadizadeh M.R., Arkivoc. (xi): 2006. 47

18. Hatamjafari F., Synthetic Communications. 2006. 36: 3563

19. Azizian J., Hatamjafari F. and Karimi A. R., Journal of Heterocyclic Chemistry. 2006.43: 1349

20. Hatamjafari F and Montazeri N., Turkish Journal of Chemistry. 2009. 33: 797

21. Hatamjafari F., Orient. J. Chem., 2012.28: 141

22. Hatamjafari F., Orient. J. Chem., 2013. 29: 93

23. Hatamjafari F and Alijanichakoli F., Orient. J.Chem., 2013.29: 145

24. Hatamjafari $F$ and Hosseinian A., Orient. J.Chem., 2013, 29: 109

25. Hatamjafari F and Khojastehkouhi H., Orient. J. Chem., 2014, 30: 329-331 .

26. Hatamjafari F and Germani Nezhad F., Orient. J. Chem., 2014, 30, 355-357. 